\title{
SIGNIFICANCE OF DETECTION OF FREE/TOTAL PSA RATIO AND OTHER BIOCHEMICAL PARAMETERS IN PATIENTS WITH BPH, CARCINOMA PROSTATE AND ITS CLINICOPATHOLOGIC CORRELATION
}

\author{
*S. Joshi', M.A.Tilak ${ }^{2}$, S. Jadhav ${ }^{2}$ \\ 1 - BHARATI VIDYAPEETH MEDICAL COLLEGE, PUNE, INDIA \\ 2 - DR. D. Y.PATIL MEDICAL COLLEGE, HOSPITAL AND RESEARCH CENTRE, PUNE, INDIA
}

Background. Benign prostatic hyperplasia (BPH) can raise prostate-specific antigen (PSA) levels two to three times higher than the normal level. An increased PSA level does not indicate Prostate Cancer (PCa), but the higher the PSA level, the higher the chance of having PCa. Detection and treatment have been profoundly affected by the advent of Free/Total PSA ratio testing.

Objectives. The aim of the study was to estimate free, total PSA levels and its ratio for serum levels of calcium, acid phosphatase and alkaline phosphatase in patients with BPH and PCa; to correlate clinical, biochemical and histopathological findings in the above patients.

Methods. PSA levels were detected by Chemiluminescent assay; serum calcium - by Modified Arsenazo method; serum acid phosphatase - by Doumas et al method; and Alkaline phosphatase - by Lowry et al method.

Results. Present study found high levels of total PSA in BPH and PCa. Levels of free PSA were high in BPH as compared to PCa rate. Free/Total PSA ratio is reduced considerably in PCa as compared to BPH. Serum acid phosphatase and alkaline phosphatase were considerably higher in PCa as compared to BPH. Serum calcium levels did not show significant difference in control and study groups.

Conclusions. It was established that patients with PCa have a greater fraction of bound PSA and a lower percentage of free PSA than in those without PCa. Therefore, in clinical practice Free/Total PSA ratio helps clinicians to decide if a biopsy is necessary.

KEYWORDS: benign prostatic hyperplasia (BPH); prostate cancer (PCa); prostate-specific antigen (PSA); free/total PSA.

\section{Introduction}

Benign prostatic hyperplasia (BPH), also called prostate enlargement, is a noncancerous increase in size of the prostate gland. Symptoms may include frequent urination, trouble starting to urinate, weak stream, inability to urinate, or loss of bladder control. Complications can include urinary tract infections, bladder stones, and chronic kidney problems [1, 2]. The clinical diagnosis of BPH typically depends on a history of LUTS (lower urinary tract symptoms), digital rectal examination. The degree of LUTS does not necessarily correspond to the size of the prostate. On rectal examination, significant finding of symmetric and smooth enlarged prostate gland is suggestive diagnosis of $\mathrm{BPH}$. However, if the prostate gland feels asymmetrical, firm, or nodular, this raises concern for prostate cancer (PCa) [2, 3]. Urinalysis is typically performed when LUTS are present and BPH is suspected to evaluate for signs of a urinary tract

*Corresponding author: Dr. Shilpa Joshi, Assistant Professor Bharati Vidyapeeth Medical College, Pune, 411043, India. E-mail: joshishilpa891@gmail.com infection, glucose in the urine (suggestive of diabetes), or protein in the urine (suggestive of kidney disease). Blood tests including kidney function tests and prostate specific antigen (PSA) are often ordered to evaluate for kidney damage and PCa, respectively. A total PSA test measures all the PSA, including both the bound and the free-floating antigens. A free PSA test, on the other hand, only measures PSA that is floating freely in the bloodstream and not bound to a different protein. Comparing the two results can help them understand the risk of PCa being present $[1,3]$. BPH and PCa are both capable of increasing blood PSA levels and PSA elevation cannot differentiate these two conditions well. If PSA levels are tested and are high, then further investigation is warranted. Measures including PSA density, free PSA, rectal examination, and transrectal ultrasonography may be helpful in determining whether a PSA increase is due to $\mathrm{BPH}$ or PCa $[2,4,5]$. Ultrasound examination of the testes, prostate, and kidneys is often performed, again to rule out cancer and hydronephrosis [2-4]. US Food and Drug Association 
(FDA) approved PSA as an auxiliary diagnostic test in the management of the patients diagnosed with PCa. Since its clinical introduction to the present time, evaluation of serum PSA level is one of the most widely used tests in urology practice $[5,6,7]$.

In conclusion Serum PSA level is very important for urologists. Introduction of PSA test into clinical practice has enabled early diagnosis of $\mathrm{PCa}$, and provided important information about its staging, and postoperative follow-up period.

The present study was performed with the aim to study free and total PSA levels in patients with $\mathrm{BPH}$ and $\mathrm{PCa}$. To aid in the early detection and diagnosis of PCa.

The study was carried out with the following objectives: to estimate free, total PSA levels and calculate Free/Total PSA ratio in patients with $\mathrm{BPH}$ and PCa, to study the serum levels of calcium, acid phosphates and alkaline phosphatase in patients with $\mathrm{BPH}$ and $\mathrm{PCa}$ and to correlate clinical, biochemical and histopathological findings in these patients.

\section{Methods}

The present prospective study was conducted in the Department of Biochemistry at Dr D. Y. Patil Medical College Hospital and Research Centre, Pune-18.

Study period: July 2012-September2014.

Study design: The study was designed as a Prospective case - control study.

\section{Ethics statement}

Written informed consents were obtained from all patients and healthy controls. Study protocols were approved by the institutional ethics committee of Dr. D. Y. Patil Vidyapeeth Pune. An informed consent was also obtained from the study population which consisted of two groups aged over 50 years old.

\section{Study group and control}

1. Control group comprises 30 healthy adults above the age of 50 years.

2. Study group comprises 35 cases of benign prostatic hyperplasia and 35 cases of Carcinoma Prostate.

Inclusion criteria: Male patients above the age of 50 years who presented with urinary complaints and showed prostatic enlargement on USG.

Exclusion criteria: Patients, who were diabetic, hypertensive and had a history of any major surgery, were excluded.

Collection of blood samples: Under all aseptic precautions about $5 \mathrm{ml}$ of venous blood was collected in a plain bulb and allowed to clot for one hour at room temperature, centrifuged at $2000 \mathrm{rpm}$ for $10 \mathrm{~min}$. Serum was separated and analysed immediately for Free PSA, Total PSA, serum calcium, serum acid posphatase and alkaline phosphatase

\section{Methods utilized:}

Free and total PSA levels: Chemiluminescent assay.

Serum Calcium: Modified Arsenazo method. Serumacid phosphatase: Doumas et al method.

Alkaline phosphatase: Lowry et al method.

Measurement of Total PSA (Chemiluminescence immunoassay method).

Electro-chemiluminescence immunoassay (ECLIA) for the quantitative determination of Total PSA in human serum and plasma $[6,7,8,9,10,11]$.

Principle: A chemical moiety is disclosed which comprises a chemical, biochemical, or biological substance attached to one or more electrochemiluminescent organometallic compounds. Substances of interest are attached to one or more ruthenium containing or osmium containing labels or other electrochemiluminescent labels. Methods for detecting small amounts of chemical moiety using chemiluminescent, electrochemiluminescent and photoluminescent means. The chemiluminescent reaction for the detection of the reaction complex is initiated by applying a voltage to the sample solution resulting in a precisely controlled reaction. Electrochemiluminescent technology can accommodate many immunoassay principles while providing superior performance $[6,7]$.

Measurement of Free PSA (Chemiluminescence method $[8,9]$.

Electro-chemiluminescence immunoassay (ECLIA) for the quantitative determination of free PSA in human serum and plasma. Measurement of free PSA is used to determine the free/total PSA ratio (\% free PSA) which can be clinically useful in evaluating the need for prostate biopsy in two ways:

A) Individual risk assessment: The \% free PSA is significantly lower in patients having prostate cancer than those with benign diseases or normal controls. The probability of finding prostate cancer with total PSA and with decreasing \% free PSA. Therefore \% free PSA improves the sensitivity and specificity in patients with total PSA values in this "gray zone".

B) Alternatively a single cut-off may be used for men in all age groups. It was found that the 
proportion of unnecessary biopsies can be reduced by $20 \%$ when using a threshold for \% free PSA of $25 \%$.

Serum Calcium: Modified Arsenazo method (end point method) $[10,11]$.

System reagent for the quantitative determination of calcium concentrations in human serum, plasma and urine on Beckman Coulter $\mathrm{AU}$ analysers.

Principle: Calcium reacts with a dye arsenazo at specific $\mathrm{pH}$ to form bluish purple coloured complex. The intensity of colour formed is directly proportional to the amount of calcium present in the sample.

This Calcium procedure is based on calcium ions $\left(\mathrm{Ca}^{2+}\right)$ reacting with Arsenazo III (2,2'-[1,8-Dihydroxy-3,6-disulphonaphthylene2,7-bisazo]- bisbenzenear-sonic acid) to form an intense purple coloured complex. Magnesium does not significantly interfere in calcium determination using Arsenazo III. In this method the absorbance of the Ca-Arsenazo III complex is measured bichromatically at $660 / 700 \mathrm{~nm}$. The resulting increase in absorbance of the reaction mixture is directly proportional to the calcium concentration in the sample.

Quality control: During operation of the Beckman Coulter AU analyser at least two levels of an appropriate quality control material should be tested a minimum of once a day. In addition, controls should be performed after calibration with each new lot of reagent, and after specific maintenance or troubleshooting steps described in the appropriate User's Guide. Quality control testing should be performed in accordance with regulatory requirements and each laboratory's standard procedure. Appropriate qualified urine controls should be established and utilized during urine analysis.

Results are automatically printed out for each sample in $\mathrm{mg} / \mathrm{dL}$ at $37^{\circ} \mathrm{C}$. For SI units $(\mathrm{mmol} / \mathrm{L})$ the results must be multiplied by 0.25 .

Serum Acid Phosphatase: Doumas et al method [12-15].

Methodology: Kinetic method.

Acid Phosphatase a-Naphtyl Phosphate. Kinetic Quantitative determination of Acid Phosphatase.

Principle: Hillmann method - acid Phosphatase activity present in the sample is determined according to the modified method of Hillmann.

a-naphtyl-phosphate $+\mathrm{H}_{2} \mathrm{O} \rightarrow$ ACP a-naphtol +Phosphate

a-naphtol + Fast Red TR $\rightarrow$ Azo Dye a-naphtol reacts with a diazoted compound forming a colour with a maximum of absorbance at $405 \mathrm{~nm}$. Tartrate is used as specific of the prostatic fraction.

Quality Control: Sera control are recommended to monitor the performance of assay procedures. If control values are found outside the defined range, check the instrument, reagents and technique for problems. Each laboratory should establish its own Quality Control scheme and corrective actions if controls do not meet the acceptable tolerances.

Alkaline Phosphatase Assay [16-18].

Alkaline Phosphatase assay on the ARCHITECT c Systems ${ }^{\text {TM }}$ and the AEROSET System.

The Alkaline Phosphatase assay is used for the quantitation of alkaline phosphatase in human serum or plasma.

Principle of procedure: Several substrates have been used to measure alkaline phosphatase activity such as glycerophosphate, phenyl phosphate and p-nitrophenyl phosphate. Bowers and McComb improved the method of Bessey et al. to include a kinetic measurement. Tietz et al. optimized this method to include a chelated metal-ion buffer of zinc, magnesium, and HEDTA. This Alkaline Phosphatase procedure is a modification of this method. Alkaline phosphatase in the sample catalyses the hydrolysis of colourless $p$-nitrophenyl phosphate ( $p$-NPP) to give $p$-nitrophenol and inorganic phosphate. At the $\mathrm{pH}$ of the assay (alkaline), the $\mathrm{p}$-nitrophenol is in the yellow phenoxide form. The rate of absorbance increase at 404 $\mathrm{nm}$ is directly proportional to the alkaline phosphatase activity in the sample. Optimized concentrations of zinc and magnesium ions are present to activate the alkaline phosphatase in the sample.

Statistical analysis: At the end of study all data was compiled and analysed statistically using Annova method, Tukey's test.

\section{Results}

Serum Free PSA, Total PSA, Free/Total PSA ratio along with serum calcium, acid phosphatase, alkaline phosphatase were estimated in 30 controls (Group I) and 35 cases each of benign prostatic hyperplasia (Group II) and carcinoma Prostate (Group III). The results showed that Total PSA levels, calcium, acid phosphatase, alkaline phosphatase were higher in Group III as compared to Group I and II. Free PSA levels and Free/Total PSA ratio was decreased in Group III as compared to Group II. (Table 1). 
The chart depicts the Mean \pm SD distribution into controls (Group I), cases (Group II) and Group (III).

Number of controls were 30 and cases were 35 each in Group II and Group III. Age of patients was considerably higher in Group III as compared to Group II (Table 2).

Table 3 shows comparison of Mean \pm SD values of serum Free PSA in Group I, II and III. Levels of Mean \pm SD values of Free PSA in Group III were significantly lower as compared to Group II.

Table 4 shows distribution of Mean \pm SD values of Total PSA in Group I, II and III.
Mean $\pm S D$ values of total PSA were found to be increased in Group III as compared to Group I and II.

Table 5 is depicting Free/Total PSA ratio in terms of Mean \pm SD in Groups I, II and III.

Mean values of serum calcium in patients with carcinoma was considerably higher as compared to benign prostatic hyperplasia and control group. Test results obtained were significant $(p<0.05)$ (Table 6).

Chart depicts intergroup comparison of serum alkaline phosphatase between cases and controls. Mean $\pm S D$ values of alkaline phosphatase were higher in Group III as compared to Groups I and II.

Table 1. Comparison of age in study groups

\begin{tabular}{|l|c|c|c|c|c|}
\hline \multirow{2}{*}{ Group } & \multirow{2}{*}{ Number } & \multicolumn{2}{|c|}{ Age (Yrs.) } & \multirow{2}{*}{ F Value } & \multirow{2}{*}{ P Value } \\
\cline { 3 - 4 } & & Mean & SD & & \\
\hline Group I (Control) & 30 & 68.07 & 7.95 & 5.04 & $<0.01$ \\
\hline Group II (Control) & 35 & 64 & 4.92 & & \\
\hline Group III (Control) & 35 & 68.26 & 5.82 & & \\
\hline
\end{tabular}

Note: Gr. I vs Gr. II: $p<0.05$ \& Gr. I vs Gr.III: $p<0.05$

$p<0.05$ : Significant

$p<0.01$ : Highly significant

$p>0.05$ and $p>0.01$ Not Significant

Table 2. Comparison of free PSA in study groups

\begin{tabular}{|l|c|c|c|c|c|}
\hline \multirow{2}{*}{ Group } & \multirow{2}{*}{ Number } & \multicolumn{2}{c|}{ Age (Yrs.) } & \multirow{2}{*}{ F Value } & \multirow{2}{*}{ P Value } \\
\cline { 3 - 4 } & & Mean & SD & & \multirow{2}{*}{39.56} \\
\hline Group I (Control) & 30 & 0.68 & 0.56 & & $<0001$ \\
\hline Group II (Control) & 35 & 2.43 & 1.10 & & \\
\hline Group III (Control) & 35 & 1.59 & 0.55 & & \\
\hline
\end{tabular}

Gr. I vs Gr. II: $p<0.0001$ andGr. I vs Gr.III: $p<0.0001$ and Gr.II vs Gr.III: $p<0.0001$

Table 3. Comparison of total PSA in study groups

\begin{tabular}{|l|c|c|c|c|c|}
\hline \multirow{2}{*}{ Group } & \multirow{2}{*}{ Number } & \multicolumn{2}{|c|}{ Age (Yrs.) } & \multirow{2}{*}{ F Value } & \multirow{2}{*}{ P Value } \\
\cline { 3 - 4 } & & Mean & SD & & \\
\hline Group I (Control) & 30 & 1.95 & 1.24 & 35.93 & $<0.0001$ \\
\hline Group II (Control) & 35 & 8.51 & 5.20 & & \\
\hline Group III (Control) & 35 & 66.83 & 58.29 & & \\
\hline
\end{tabular}

Gr. I vs Gr. II: $p<0.0001$ \& Gr. I vs Gr.III: $p<0.0001$

Table 4. Comparison of free/total PSA ratio in study groups

\begin{tabular}{|l|c|c|c|c|c|}
\hline \multirow{2}{*}{ Group } & \multirow{2}{*}{ Number } & \multicolumn{2}{|c|}{ Age (Yrs.) } & \multirow{2}{*}{ F Value } & \multirow{2}{*}{ P Value } \\
\cline { 3 - 4 } & & Mean & SD & & \\
\hline Group I (Control) & 30 & 0.34 & 0.15 & 95.29 & $<0.0001$ \\
\hline Group II (Control) & 35 & 0.32 & 0.09 & & \\
\hline Group III (Control) & 35 & 0.04 & 0.03 & & \\
\hline
\end{tabular}

Gr. I vs Gr. II: $p<0.0001$ \& Gr. I vs Gr.III: $p<0.0001$ 
Table 5. Comparison of serum calcium in study groups

\begin{tabular}{|l|c|c|c|c|c|}
\hline \multirow{2}{*}{ Group } & \multirow{2}{*}{ Number } & \multicolumn{2}{|c|}{ Age (Yrs.) } & \multirow{2}{*}{ F Value } & \multirow{2}{*}{ P Value } \\
\cline { 3 - 4 } & & Mean & SD & & $<0.05$ \\
\hline Group I (Control) & 30 & 9.19 & 0.41 & 4.20 & \\
\hline Group II (Control) & 35 & 9.18 & 0.48 & & \\
\hline Group III (Control) & 35 & 9.52 & 0.71 & & \\
\hline
\end{tabular}

Gr. I vs Gr. II: $p<0.05$ \& Gr. I vs Gr.III: $p<0.05$

$p<0.05$ : Significant

$p<0.01$ : Highly significant

$p>0.05$ and $p>0.01$ Not Significant

Table 6. Comparison of serum acid phosphatase in study groups

\begin{tabular}{|l|c|c|c|c|c|}
\hline \multirow{2}{*}{ Group } & \multirow{2}{*}{ Number } & \multicolumn{2}{|c|}{ Age (Yrs.) } & \multirow{2}{*}{ F Value } & \multirow{2}{*}{ P Value } \\
\cline { 3 - 5 } & & Mean & SD & & \\
\hline Group I (Control) & 30 & 4.65 & 0.93 & 36.31 & $<0.0001$ \\
\hline Group II (Control) & 35 & 5.30 & 1.51 & & \\
\hline Group III (Control) & 35 & 18.52 & 12.67 & & \\
\hline
\end{tabular}

Gr. I vs Gr. II: $p<0.001$ andGr. I vs Gr.III: $p<0.0001$

Table 7. Comparison of serum alkaline phosphatase in study groups

\begin{tabular}{|l|c|c|c|c|c|}
\hline \multirow{2}{*}{ Group } & \multirow{2}{*}{ Number } & \multicolumn{2}{c|}{ Age (Yrs.) } & \multirow{2}{*}{ F Value } & \multirow{2}{*}{ P Value } \\
\cline { 3 - 4 } & & Mean & SD & & $<0.0001$ \\
\hline Group I (Control) & 30 & 51.90 & 13.09 & 42.20 & \\
\hline Group II (Control) & 35 & 71.20 & 29.58 & & \\
\hline Group III (Control) & 35 & 112.49 & 33.6 & & \\
\hline
\end{tabular}

Gr. I vs Gr. II: $p<0.0001$ and Gr. I vs Gr.III: $p<0.05$ and Gr.II vs Gr.III: $p<0.0001$

\section{Discussion}

PCa is a major cancer and leading cause of death in men. As with any cancer, early detection followed by treatment increases the disease-free survival rate significantly. Early diagnosis is very important in management of any type of cancer and infections. After introduction of serum PSA measurements into clinical use, the incidence rate of early diagnosis has increased, and a shift between stages was achieved. Nowadays, $70-80 \%$ of the diagnosed cancers are organ-confined $[18,19]$.

Serum PSA level was also helpful in the staging of $\mathrm{PCa}$. serum PSA values between $0-4 \mathrm{ng} / \mathrm{mL}$ can detect $80 \%$ of the organ-confined disease, while PSA values between $4-10 \mathrm{ng} / \mathrm{mL}$, and above $10 \mathrm{ng} / \mathrm{mL}$ were found in $70 \%$ and $50 \%$ of the cases with organ-confined disease. Serum PSA levels also provide us helpful information about lymph node involvement. Lymph node involvement has been also reported in men with serum PSA levels of $<10 \mathrm{ng} / \mathrm{mL}(5 \%)$, $10-20 \mathrm{ng} / \mathrm{mL}(18 \%)$, and $>20 \mathrm{ng} / \mathrm{mL}(20 \%)$ in respective percentages. Therefore, if serum PSA level is below $25 \mathrm{ng} / \mathrm{mL}$, there is no need to perform CT or MRI, and bone scanning is not required for men with serum PSA levels below $20 \mathrm{ng} / \mathrm{mL}$. Besides, it has been demonstrated that in men with Gleason score $\leq 6$, clinical stage $\mathrm{T} 1 / \mathrm{T} 2$, and serum PSA levels below $10 \mathrm{ng} / \mathrm{mL}$, lymph node dissection is not required $[1,3,4$, $12,18,19]$.

The current prospective study was conducted with the aim to estimate Free PSA, Total PSA, Free/Total PSA ratio in patients with benign $\mathrm{BPH}$ and $\mathrm{PCa}$ and correlate with the histopathology report. In the present study age wise distribution in control group is $68.07 \pm 7.95$, while in $\mathrm{BPH}$ it was $64 \pm 4.92$ and in $\mathrm{PCa}$ $68.26 \pm 5.82$. There was no significant difference in the age wise distribution among all the three groups. Mean values of Free PSA levels in benign prostatic hyperplasia were $2.43 \pm 1.10 \mathrm{ng} / \mathrm{ml}$, in carcinoma prostate $-1.59 \pm 0.55 \mathrm{ng} / \mathrm{ml}$ as compared to $0.68 \pm 0.56 \mathrm{ng} / \mathrm{ml}$ in the control group. The result was statistically highly significant $(p<0.0001)$. In the present study, free/total PSA ratio is reduced in carcinoma prostate as compared to benign prostatic hyperplasia. Histological grades of prostate 
biopsy showed a negative correlation with free/ total PSA ratio in our study.

Lakhey M et al (2010) reported serum free PSA is elevated marginally in patients with $\mathrm{BPH}$ without inflammation, determined the relationship between free PSA and histological findings in biopsy specimens of patients with prostate disease. Active inflammation and highgrade lesions are associated with free PSA level more than $5 \mathrm{ng} / \mathrm{ml}$ [18].

Ari Adamy et al (2011) reported that with prostate specific antigen included in progression criteria prostate specific antigen at confirmatory biopsy (HR 1.29, 95\% CI 1.14-1.46, p<0.0005) and positive confirmatory biopsy (HR 1.75, 95\% CI $1.01-3.04, p=0.047$ ) were independent predictors of progression [19].

Measurement of serum PSA levels is very important during post-treatment monitorization of PCa. Besides based on preoperative serum PSA levels, a biochemical recurrence can be seen within 10 years after surgery. Accordingly, recurrence rates of 10,20 , and $50 \%$ are anticipated in men with preoperative serum PSA levels of $<2.6 \mathrm{ng} / \mathrm{mL}$, 2.6-10 ng/mL, and above $10 \mathrm{ng} / \mathrm{mL}$, respectively. Serum PSA levels are important in patients who had undergone androgen suppression therapy because of metastatic disease. If serum PSA level does not drop below $4 \mathrm{ng} / \mathrm{mL} 7$ months after androgen suppression therapy, median life-expectancy of these patients is only one year. If serum PSA levels of these patients drop below $0.2 \mathrm{ng} / \mathrm{mL}$, then median life-expectancy longer than 6 years can be predicted. If after radical prostatectomy or radiotherapy, serum PSA levels of the patients without radiological metastases rise above $0.2 \mathrm{ng} / \mathrm{mL}$ within the first 8 months of androgen suppression, prostate cancer mortality increases 20 -fold. Still PSA doubling time shorter than 3 months is a very bad prognostic finding. Increase in serum PSA levels after prostatectomy aids in differentiation between local and systemic recurrences. If PSA doubling time increases after the first 2 postoperative years, and PSA doubling time is longer than 11 months, then local recurrence should be conceived with an $80 \%$ probability. However, if PSA levels rise within the first postoperative year, and PSA doubling time is 4-6 months, the systemic disease should be thought of with a $80 \%$ probability.

Similar results were obtained in a prospective study by Muhittin Serdar et al (2002) reported patients with serum total PSA between 4.1$9.9 \mathrm{ng} / \mathrm{ml}$, if none of the PSA-based parameters is positive, biopsy can be postponed and the patients should be followed-up; on the other hand, patients with three positive parameters should be biopsied. If only one or two of the parameters are positive, the patient's age, race, and clinical findings should be considered in decision-making. Hence, the combined use of all markers can increase sensitivity and specificity [20].

Cut off value of free/total PSA ratio is 0.14 (14\%) in the present study which has sensitivity of $94.3 \%$ and specificity of $99 \%$. Patients with less than 0.14 ratio had Carcinoma prostate as compared to those above with cut off which showed benign prostatic hyperplasia. Most PSA in the blood is bound to other proteins. Normally more than $23 \%$ of serum PSA is in its free form (free PSA). Benign prostatic tumours may be associated with elevated PSA, especially free PSA. With prostate carcinoma, however, the proportion of free PSA decreases. One theory hypothesizes that prostate carcinoma produces not only PSA but also proteins to which the PSA is bound. As a result, portion of free PSA decreases. Histological grades showed a negative correlation between free/total PSA ratio and histological grade of carcinoma.

A lower ratio suggests prostate carcinoma while higher ratio suggests BPH by Borros Arneth [21]. In our study, total PSA and free/ total PSA ratio were in accordance with study by $D$ Weckermann et al in which the patients with prostate cancer showed high total PSA and reduced free/total PSA ratio as compared to $\mathrm{BPH}$ patients. Mione R et al found that percent free PSA was more effective than total PSA in the differential diagnosis between carcinoma prostate and BPH. Percent free PSA is superior to total PSA in distinguishing between primary Carcinoma prostate from $\mathrm{BPH}$, in patients with total PSA between $2-30 \mathrm{ng} / \mathrm{ml}$ [22].

According to Manabu Kuriyama et al [23] the diagnostic significance of free/total PSA has been reported to improve diagnostic accuracy of prostate cancer in the group with considerably elevated serum PSA values. As serum PSA values increased, $\mathrm{f} / \mathrm{t}$ was lower in the carcinoma prostate 56 group than in non-prostate carcinoma group. However, $\mathrm{f} / \mathrm{t}$ values were lower in prostate carcinoma group than in non-prostate carcinoma group. The positive predictive value for prostate cancer increased to $54 \%$ in total PSA alone. Cut off value of free/total was 0.155 for obtaining relatively high specificity. In the present study, sensitivity was $85 \%$ and specificity was $56.5 \%$. 
Levels of calcium in serum were significantly correlated with serum levels of free PSA. It is unlikely that serum PSA acts to increase serum calcium, whose serum levels are under strict homeostatic control. Specifically, if serum levels of PSA increased serum levels of calcium, the men with advanced prostate cancer would develop hypercalcemia.

In this study probability estimates for prostate cancer in the percent free PSA ranges of $\leq 10 \mathrm{ng} / \mathrm{ml}$ is $58.3 \%$. Although diagnostic improvements have been made through the use of PSA quotient, the diagnosis of prostate carcinoma can be made only after tumour biopsy and histopathology examination. Since the introduction of prostate-specific antigen testing over two decades ago, there has been a steep increase in the prostate cancer incidence, especially the incidence of localized low risk disease. Use of the percentage free PSA can enhance the specificity of PSA testing and decrease the number of unnecessary biopsies. However, the cut off free/total PSA in our case was $18.0 \%$. Use of percent free PSA has been shown to improve specificity in the detection of prostate (4.1-10 ng/ml). In our study $17(22 \%)$ patients had total PSA levels between $4-10 \mathrm{ng} / \mathrm{ml}$. Of these one of the patients had PSA level $6.6 \mathrm{ng} / \mathrm{ml}$, which on biopsy was reported as carcinoma prostate. Remaining 16 patients were reported as BPH on biopsy. Other parameters like serum calcium showed mean values of $9.91 \pm 0.41 \mathrm{mg} / \mathrm{dl}$ in the control group. In $\mathrm{BPH}$ and PCa mean values of serum calcium were $9.18 \pm 0.48 \mathrm{mg} / \mathrm{dl}$ and $9.52 \pm 0.71 \mathrm{mg} / \mathrm{dl}$, respectively. In the present study acid phosphatase values were higher in Group III (Carcinoma) as compared to group I and II. However, with advent of Prostate Specific Antigen (PSA) measurement of acid phosphatase in the diagnosis, staging and monitoring of prostate cancer has taken a back stage. Human prostatic acid phosphatase is a prostate epithelium specific differentiation antigen found in large amounts initially in seminal fluid. In our study $5(14.28 \%)$ out of 35 patients were found to have slightly elevated acid phosphatase levels. Only one patient showed bone metastases. Similar study by Gutman and his colleagues made the critical observation that serum prostate acid phosphatase activity was significantly higher in prostate cancer patients, particularly those with bone metastases.

Limitation of the study is that in the present study per rectal examination was not done, as it was not advised by clinicians.

\section{Conclusions}

Present study found high levels of Total PSA in BPH and PCa. The levels of free PSA were high in BPH as compared to PCa rate. Free/Total PSA ratio was reduced considerably in PCa as compared to BPH. Serum acid phosphatase and alkaline phosphatase were considerably higher in PCa as compared to BPH. Serum calcium levels did not show significant difference in the control and study groups. We concluded that the patients with PCa have a greater fraction of bound PSA and a lower percentage of free PSA than in those without $\mathrm{PCa}$. There was a negative correlation found between free/total PSA ratio and the histopathologic findings. The lower is the ratio, the higher is the grade of malignancy. Therefore, in clinical practice Free/Total PSA ratio helps clinicians to decide if a biopsy is necessary.

\section{Conflict of Interests}

The authors declare no conflict of interest.

\section{Acknowledgements}

The authors acknowledge all technical support by the technical staff of Biochemistry Department of Dr. D.Y. Patil Medical College Hospital and Research Centre Pimpri, Pune.

\section{Author's Contributions}

Dr. Shilpa Joshi - conceptualization, methodology, practical work, formal analysis; Dr. Mona Tilak-guidance in research work, investigation and analysis; Dr. Savita Jadhav - writing original draft, reviewing and editing draft, finalization of draft. 


\title{
КЛІНІКО-ПАТОЛОГІЧНА КОРЕЛЯЦІЯ ТА РОЛЬ СПІВВІДНОШЕННЯ ВІЛЬНОГО/ЗАГАЛЬНОГО ПРОСТАТОСПЕЦИФІЧНОГО АНТИГЕНУ ТА ІНШИХ БІОХІМІЧНИХ ПОКАЗНИКІВ У ПАЦІЄНТІВ 3 ДОБРОЯКІСНОЮ ГІПЕРПЛАЗІЕЮ ПЕРЕДМІХУРОВОЇ ЗАЛОЗИ ТА КАРЦИНОМОЮ ПРОСТАТИ
}

\author{
*S. Joshi', M.A.Tilak², S. Jadhav² \\ 1 - BHARATI VIDYAPEETH MEDICAL COLLEGE, PUNE, INDIA
}

2 - DR. D. Y.PATIL MEDICAL COLLEGE, HOSPITAL AND RESEARCH CENTRE, PUNE, INDIA

Вступ. Доброякісна гіперплазія передміхурової залози (ДГПз) може супроводжуватися відвічі-втричі підвищеним рівнем (ПСА). Підвищений рівень ПСА не вказує на рак передміхурової залози (РПЗ), чим вищий рівень ПСА, тим більша ймовірність виникнення РПЗ. Поява тесту на співвідношення вільного/загального ПСА мала значний вплив на частототу виявлення та вибір тактики лікування РПз.

Мета. Оцінити співвідношення вільного/загального ПСА, рівень сироваткового кальцію, кислої та лужної фосфатаз у пацієнтів з ДГПз та РПЗ. Провести кореляцію клінічних, біохімічних та гістопатологічних даних у вищевказаних пацієнтів.

Методи. Визначення ПСА проводилося за допомогою хемілюмінесцентного аналізу; сироватковий кальцій визначався модифікованим методом арсеназо. Кисла фосфатаза сироватки визначалася методом за Doumas et al., лужна фосфатаза - за Lowry et al.

Результати. Дослідження виявило високі рівні загального ПСА при ДГПЗ та РПЗ. Рівні вільного ПСА були вищими при ДГПз порівняно з РПЗ. Співвідношення вільного/загального ПСА значно знижується при РПЗ порівняно з ДГПЗ. Рівні сироваткової кислої та лужної фосфатаз значно підвищуються при РПЗ порівняно з ДГПз. Рівень кальцію в сироватці крові не відрізнявся в контрольній та досліджуваній групах.

Висновки. Пацієнти з РПз мають більшу частку зв'язаного ПСА та менший відсоток вільного ПСА, порівняно з пацієнтами без РПз. Тому в клінічній практиці співвідношення вільного/загального ПСА може допомогти клініцистам вирішити чи потрібна біопсія.

КЛючОВІ СЛОВА: доброякісна гіперплазія передміхурової залози (ДГпЗ); рак передміхурової залози (РПЗ); простатоспецифічний антиген (ПСА); вільний/загальний ПСА.

\section{Information about the authors}

Dr. Shilpa Joshi, Assistant Professor, Bharati Vidyapeeth Medical College, Pune, India

ORCID: 0000-0003-0331-6425, email: joshishilpaa891@gmail.com

Dr. Mona Tilak, Professor, Head of the Department, Dr. D.Y.Patil Medical College, Hospital and Research Centre Pimpri, Pune, India

ORCID: 0000-0002-1734-8295, email: drmonatilal@dpu.edu.in India

Dr. Savita Jadhav, Professor, D.Y.Patil Medical College, Hospital and Research Centre Pimpri, Pune,

ORCID: 0000-0003-3439-9462, email: patilsv78@gmail.com

\section{References}

1. Avci S, Onen E, Caglayan V, Kilic M, Sambel M, Oner S. Free prostate-specific antigen outperforms total prostate-specific antigen as a predictor of prostate volume in patients without prostate cancer. Arch Ital Urol Androl. 2020 Apr 6;92(1):1-6.

DOI: 10.4081/aiua.2020.1.1. PMID: 32255313.

2. Mao Q, Zheng $X$, Jia $X$, Wang $Y$, Qin J, Yang K, Bai $Y$, Xie L. Relationships between total/free prostate-specific antigen and prostate volume in Chinese men with biopsy-proven benign prostatic hyperplasia. Int Urol Nephrol. 2009 Dec;41(4):761-6.

DOI: 10.1007/s11255-009-9533-1. Epub 2009 Feb 18. PMID: 19224388.

3. Coban S, Doluoglu OG, Keles I, Demirci $H$ Turkoglu AR, Guzelsoy M, Karalar M, Demirbas M.
Age and total and free prostate-specific antigen levels for predicting prostate volume in patients with benign prostatic hyperplasia. Aging Male. 2016 Jun;19(2):124-7.

DOI: 10.3109/13685538.2015.1131260. Epub 2016 Feb 12. PMID: 26872869.

4. Garvey $B$, Türkbey $B$, Truong $H$, Bernardo $M$, Periaswamy S, Choyke PL. Clinical value of prostate segmentation and volume determination on MRI in benign prostatic hyperplasia. Diagn Interv Radiol. 2014 May-Jun;20(3):229-33.

DOI: 10.5152/dir.2014. 13322. PMID: 24675166; PMCID: PMC4463345.

5. Grossfeld GD, Coakley FV. Benign prostatic hyperplasia: clinical overview and value of diagnostic 
imaging. Radiol Clin North Am. 2000 Jan;38(1):31-47. doi: 10.1016/s0033-8389(05)70148-2. PMID: 10664665.

6. Abbott L. et al. Acid phosphatase. Kaplan A et al. Clin Chem The C.V. Mosby Co. St Louis. Toronto. Princeton 1984; 1079-1083.

7. Young DS. Effects of drugs on Clinical Lab. Tests, 4th ed AACC Press, 1995.

8. Young DS. Effects of disease on Clinical Lab. Tests, 4th ed AACC 2001.

9. Allhoff EP, Proppe KH, Chapman CM, Lin CW, Prout GRJr. Evaluation of prostate specific acid phosphatase and prostate specific antigen in identification of prostatic cancer. J Urol. 1983 Feb;129(2):315-8.

DOI: 10.1016/s0022-5347(17)52074-1. PMID: 6339742

10. Bruzzese D, Mazzarella C, Ferro M, Perdonà S, Chiodini P, Perruolo G, Terracciano D. Prostate health index vs percent free prostate-specific antigen for prostate cancer detection in men with "gray" prostate-specific antigen levels at first biopsy: systematic review and meta-analysis. Transl Res. 2014 Dec; 164(6):444-51.

DOI: 10.1016/j.trsl.2014.06.006. Epub 2014 Jun 26. PMID: 25035153.

11. Woolf $\mathrm{SH}$, Krist A. Shared decision making for prostate cancer screening: do patients or clinicians have a choice? Arch Intern Med 2009;169:1557-9.

12. Wolf AM, Wender RC, Etzioni RB, Thompson IM, D'Amico AV, Volk RJ, et al. American Cancer Society Prostate Cancer Advisory Committee. American Cancer Society guideline for the early detection of prostate cancer: update 2010. CA Cancer J Clin 2010;60:70-98.

13. Barisiene M, Bakavicius A, Stanciute D, Jurkeviciene J, Zelvys A, Ulys A, Vitkus D, Jankevicius F. Prostate Health Index and Prostate Health Index Density as Diagnostic Tools for Improved Prostate Cancer Detection. Biomed Res Int. 2020 Jul 21;2020: 9872146.

DOI: 10.1155/2020/9872146. PMID: 32775459; PMCID: PMC7396080.

14. Sasaki M, Ishidoya S, Ito A, Saito H, Yamada S, Mitsuzuka K, Kaiho Y, Shibuya D, Yamaguchi T, Arai Y. Low percentage of free prostate-specific antigen (PSA) is a strong predictor of later detection of prostate cancer among Japanese men with serum levels of total PSA of $4.0 \mathrm{ng} / \mathrm{mL}$ or less. Urology. 2014 Nov;84(5):1163-7.

DOI: 10.1016/j.urology.2014.04.055. Epub 2014 Oct 24. PMID: 25443923.

15. Huang, Yan MD; Li, Zhen-Zhen MDa; Huang,
Ya-Liang MD; ${ }^{b}$ Song, Hong-Jun BDc; Wang, YouJuan $\mathrm{MD}^{\mathrm{a},{ }^{*}}$ Value of free/total prostate-specific antigen ( $f / t$ PSA) ratios for prostate cancer detection in patients with total serum prostate-specific antigen between 4 and $10 \mathrm{ng} / \mathrm{mL}$, Medicine: March 2018. Volume 97, Issue 13, p e0249

DOI: 10.1097/MD.0000000000010249

16. Lakhey M, Ghimire R, Shrestha R, Bhatta AD. Correlation of serum free prostate-specific antigen level with histological findings in patients with prostatic disease. Kathmandu Univ Med J (KUMJ). 2010 Apr-Jun;8(30):158-63.

DOI: 10.3126/kumj.v8i2.3550. PMID: 21209527.

17. Adamy A,Yee DS,Matsushita K,et al .Role of prostate specific antigen and immediate confirmatory biopsy in predicting progression during active surveillance for low risk prostate cancer. J Urol2011 Feb;185(2):477-82.

18. Muhittin Serdar,\& Oguz, Ozkan \& Olgun, Abdullah \& Seçkin, Bedrettin \& Ilgan, Seyfettin \& haşimi, Adnan \& Salih, Mustafa \& Peker, Fuat \& Kutluay, Turker. (2002). Diagnostic approach to prostate cancer using total prostate specific antigenbased parameters together. Annals of clinical and laboratory science. 32. 22-30.

19. Borros M. Arneth, Clinical Significance of Measuring Prostate-Specific Antigen, Laboratory Medicine, Volume 40, Issue 8, August 2009, Pages 487-491.

20. Ito $\mathrm{K}$, Yamamoto $\mathrm{T}$, Ohi $\mathrm{M}$, Kurokawa $\mathrm{K}_{\text {, }}$ Suzuki K, Yamanaka H. Free/total PSA ratio is a powerful predictor of future prostate cancer morbidity in men with initial PSA levels of 4.1 to $10.0 \mathrm{ng} / \mathrm{mL}$. Urology. 2003 Apr;61(4):760-4.

DOI: 10.1016/s0090-4295(02)02427-5. PMID: 12670561.

21. Mione R, Barioli P, Barichello M, et al. Prostate Cancer Probability after Total PSA and Percent Free PSA Determination. Australian \& New Zealand Journal of Psychiatry. 1998;13(2):331-339.

22. Manabu Kuriyama, Yukimichi Kawada, Yoichi Arai, Hiroshi Maeda, Shin Egawa, Ken Koshiba, Kyoichi Imai, Hidetoshi Yamanaka, Significance of Free to Total PSA Ratio in Men with Slightly Elevated Serum PSA Levels: A Cooperative Study, Japanese Journal of Clinical Oncology, Volume 28, Issue 11, November 1998, Pages 661-665.

Received 24 Apr 2021; revised 20 May 2021; accepted 10 Jun 2021.

This is open access article distributed under the Creative Commons Attribution License, which permits unrestricted use, distribution, and reproduction in any medium, provided the original work is properly cited. 